[This document contains the author's accepted manuscript. For the publisher's version, see the link in the header of this document.]

Paper citation: Sabarwal, Tarun (2005): "The Non-Neutrality of Debt in Investment Timing: A New NPV Rule," Annals of Finance, 1(4), 433-445

Keywords: Debt, Default, Limited Liability, Investment, NPV, Option Value

Abstract: Limited liability debt financing of irreversible investments can affect investment timing through an entrepreneur's option value, even after compensating a lender for expected default losses. This non-neutrality of debt arises from an entrepreneur's unique investment opportunity, and it is shown in a standard model of irreversible investment that is enhanced in a straightforward manner to include the equilibrium effect of a competitive lending sector. The analysis is partial, in that it takes as exogenously given an entrepreneur's use of debt. Intuitively, limited liability lowers downside risk for the entrepreneur by truncating the lower tail of risks, thereby lowering the investment threshold. Compensating the lender for expected default losses reduces project profitability to the entrepreneur, thereby increasing the investment threshold. The net effect is negative, because lower downside risk has an additional impact on the option value of delaying investment. The standard NPV rule in real options theory implicitly assumes debt to be neutral. With non-neutrality of debt, an investment threshold is higher than investment cost, but lower than the standard NPV rule. Comparisons with other standard investment thresholds show similar relationships. 


\title{
The Non-Neutrality of Debt in Investment Timing: A New NPV Rule
}

\author{
Tarun Sabarwal ${ }^{1}$ \\ Department of Economics, BRB 1.116 \\ The University of Texas at Austin \\ 1 University Station C3100 \\ Austin TX 78712-0301, USA \\ sabarwal@eco.utexas.edu
}

This Version: April 8, 2005

JEL Numbers: G00, D92, E50

Keywords: Debt, Default, Limited Liability, Investment, NPV, Option Value

\footnotetext{
${ }^{1}$ The author is deeply grateful to Bob Anderson for his advice and encouragement. He thanks Joydeep Bhattacharya, Svetlana Boyarchenko, Gabriele Camera, Helios Herrera, Warren Hrung, Dwight Jaffee, Sergei Levendorskii, Preston McAfee, Chris Shannon, Max Stinchcombe, and referees for helpful comments.
} 


\title{
The Non-Neutrality of Debt in Investment Timing: A New NPV Rule
}

\begin{abstract}
Limited liability debt financing of irreversible investments can affect investment timing through an entrepreneur's option value, even after compensating a lender for expected default losses. This non-neutrality of debt arises from an entrepreneur's unique investment opportunity, and it is shown in a standard model of irreversible investment that is enhanced in a straightforward manner to include the equilibrium effect of a competitive lending sector. The analysis is partial, in that it takes as exogenously given an entrepreneur's use of debt. Intuitively, limited liability lowers downside risk for the entrepreneur by truncating the lower tail of risks, thereby lowering the investment threshold. Compensating the lender for expected default losses reduces project profitability to the entrepreneur, thereby increasing the investment threshold. The net effect is negative, because lower downside risk has an additional impact on the option value of delaying investment. The standard NPV rule in real options theory implicitly assumes debt to be neutral. With non-neutrality of debt, an investment threshold is higher than investment cost, but lower than the standard NPV rule. Comparisons with other standard investment thresholds show similar relationships.
\end{abstract}


Sabarwal, Tarun (2005): "The Non-Neutrality of Debt in Investment Timing: A

New NPV Rule," Annals of Finance, 1(4), 433-445. Publisher's official version: <http://dx.doi.org/10.1007/s10436-005-0016-9>.

Open Access version: http://kuscholarworks.ku.edu/dspace/.

\section{Introduction}

The Modigliani-Miller theorem (1958) guarantees that the mix of debt and internal financing does not affect the overall value of a firm, or as is the case in this paper, the overall value of an investment project. It implies that a financing decision cannot be used to increase the overall value of a project, and therefore, it obviates theoretical arguments about any role of debt financing in an investment decision. ${ }^{2}$ In practice, debt financing appears to play a significant role in investment decisions; for example, aggregate debt growth rates are wellknown to be pro-cyclical for both households and firms, there is a literature on the role of debt financing on real estate construction decisions, there is another literature on the effects of financing on firm decisions, and there is a further literature on the role of debt financing on household financial decision-making.

Exceptions to the Modigliani-Miller theorem, including explanations for its observed violations, usually rely on some form of market imperfection, including tax distortions, agency costs, market power, other deadweight losses, and so on.

This paper presents another exception to the Modigliani-Miller theorem. Using ideas regarding value of waiting that have been formalized in real options theory, it is shown that if an investment option resides with an entrepreneur, (as opposed to a lender,) then even after compensating a lender for expected default losses, limited liability debt financing affects optimal investment timing by affecting an entrepreneur's value of waiting. ${ }^{3}$ In particular, with such debt financing, the optimal investment threshold is lower than that consistent

\footnotetext{
${ }^{2}$ The well-known result by Merton (1977) shows the validity of the Modigliani-Miller theorem even with a positive probability of bankruptcy, an application of this theorem to Arrow-Debreu economies is given in Stiglitz (1969), and another application to open market operations is given in Wallace (1981).

${ }^{3}$ For a development of real options theory, see the seminal papers by McDonald and Siegel (1986), Pindyck (1988), Dixit (1989), and others. More recent work is presented in the collection by Brennan and Trigeorgis (2000). For generalizations to non-Gaussian processes, see Boyarchenko and Levendorski (2000), and Boyarchenko (2003).
} 
Sabarwal, Tarun (2005): "The Non-Neutrality of Debt in Investment Timing: A

New NPV Rule," Annals of Finance, 1(4), 433-445. Publisher's official version: <http://dx.doi.org/10.1007/s10436-005-0016-9>.

Open Access version: http://kuscholarworks.ku.edu/dspace/.

with the standard theory of irreversible investment under uncertainty, but higher than cost of investment. Therefore, whereas the classical NPV rule of investment (invest at the first time when present value exceeds cost of investment) does not consider the value of waiting for new information, and gives a threshold that is too low, the standard NPV rule of irreversible investment under uncertainty (invest at the first time when present value exceeds a multiple of investment cost) does not consider the effect of limited liability on the value of waiting, and gives a threshold that is too high.

Consider an entrepreneur who finances an investment cost $I$ with debt $D \leq I$ using a simple, limited liability debt contract. ${ }^{4}$ The lender has a first claim on project revenues up to a fixed coupon $C$, determined by the lender's zero profit condition. If revenue is below $C$, the entrepreneur's liability is limited to available revenue, and she turns over the entire revenue to the lender. In this case, there are several effects of debt financing on the optimal investment threshold. To the extent that debt reduces an entrepreneur's share of investment cost, the investment threshold is lower, and to the extent that limited liability lowers downside risk of the project, the investment threshold is lower. But default is not costless, because the lender anticipates its probability, and sets coupon in part to offset expected losses. To the extent a higher coupon decreases project profitability for

\footnotetext{
${ }^{4}$ The analysis here does not explicitly consider a reason for debt financing, but takes the decision about debt as given, assumes that the entrepreneur can finance the remainder from either an endowment, or equivalently, from existing internal funds, and focuses on the effect of debt on the optimal investment threshold. In particular, a priori, there is no guarantee that optimal debt is not zero. The debt contract assumed here is a reduced-form of the simple debt contract that is optimal in the costly state verification (CSV) model of Townsend (1979). In a more recent paper, Krasa and Villamil (2000) show that among other things, the CSV model can be thought of as a reduced-form of a more fundamental model with limited committment and with costly enforcement as a decision variable, and in such a model, simple debt remains an optimal contract. Qualitative effects of alternative limited liability debt contracts are the same, as described below.
} 
Sabarwal, Tarun (2005): "The Non-Neutrality of Debt in Investment Timing: A

New NPV Rule," Annals of Finance, 1(4), 433-445. Publisher's official version: <http://dx.doi.org/10.1007/s10436-005-0016-9>.

Open Access version: http://kuscholarworks.ku.edu/dspace/.

the entrepreneur, the investment threshold is higher. Moreover, a lower default probability decreases coupon, increases project profitability for the entrepreneur, and therefore, lowers the investment threshold, and similarly, a higher default probability raises coupon, reduces project profitability, and raises the threshold. What might be the net effect of such debt financing on the optimal investment threshold? Intuitively, one might expect that after compensating the lender for expected default losses, its net effect is zero. In contrast, the analysis here shows that the net effect is not zero; in fact, it is negative.

The non-neutrality of debt can be viewed in terms of a skewed evaluation of a meanpreserving spread in an entrepreneur's option value. Recall that option value derives in part from an ability to avoid downside risk; that is, in case of adverse realizations, an option does not have to be exercised, and therefore, other things equal, if downside risk of a project is lower, (its option value is lower, and) its investment threshold is lower. With limited liability, some of the downside risk is transferred to the lender, and from an entrepreneur's viewpoint, the lower tail of risks is truncated. This has two effects - one on project value, and the other on option value. The mean-preserving aspect arises from the lender's zero profit condition, and it implies an equal and opposite impact on total project value. The skewed evaluation arises from an additional impact of the truncation of the lower tail of risks on the entrepreneur's option value. Limited liability reduces downside risk, and this has an additional negative impact on an entrepreneur's option value, thus lowering the investment threshold.

The formal analysis in this paper is based on a straightforward extension of a simple version of a well-established model (Pindyck (1988), and McDonald and Siegel (1986)) of irreversible investment to include a competitive lending sector, and it yields a closed-form solution for the optimal investment threshold. ${ }^{5}$ A unique feature of this analysis is the intro-

\footnotetext{
${ }^{5}$ As mentioned in Pindyck (1991), examples of irreversible investments include investments that are specific to a firm or industry, (for example, a large, industry-specific production unit,) investments the resale
} 
Sabarwal, Tarun (2005): "The Non-Neutrality of Debt in Investment Timing: A

New NPV Rule," Annals of Finance, 1(4), 433-445. Publisher's official version: <http://dx.doi.org/10.1007/s10436-005-0016-9>.

Open Access version: http://kuscholarworks.ku.edu/dspace/.

duction of a lending sector, and consequently, an endogenous determination of the coupon or interest rate on debt based on the equilibrium feedback from the lending sector. An appealing feature of this analysis is that it provides an equilibrium solution that is unique, analytically tractable, and intuitive. The equilibrium solution allows a natural decomposition of the optimal threshold into two parts, one that can be compared directly to the standard model of irreversible investment under uncertainty, and another that arises from the introduction of debt financing, thereby facilitating a better understanding of the impact of debt financing on optimal investment thresholds.

The paper proceeds as follows. Section 2 specifies the model, defines an equilibrium, and shows the existence of a unique equilibrium. Section 3 discusses the new NPV rule, and relates it to some established notions in the theory of investment under uncertainty.

\section{Specification of the Model}

The model in this paper adapts a simple version of a well-established model (Pindyck (1988), and McDonald and Siegel (1986)) of irreversible investment to include a competitive lending sector. To facilitate comparison to the standard model, notation from Dixit and Pindyck (1994) is used. Suppose, as usual, that an entrepreneur is considering an irreversible investment in a project with a fixed scale, infinite life, and no marginal cost. If inverse demand for project output is $P=Y \cdot D(Q)$, where $P$ is price of the firm's output, $Q$ is quantity of output, and $Y$ a stochastic shift variable, then fixing $Q=1$ allows $P$ to be the stochastic variable, and $P$ follows a geometric brownian motion with drift, given by $d P=\alpha P d t+\sigma P d W$. Let $\mu$ be the discount rate for future revenues, and let $\delta=\mu-\alpha>0$.

The cost of investment is $I$. The investment is irreversible, in the sense that the investof which involve informational asymmetries, and investments that cannot be divested because of government or institutional restrictions. 
Sabarwal, Tarun (2005): "The Non-Neutrality of Debt in Investment Timing: A

New NPV Rule," Annals of Finance, 1(4), 433-445. Publisher's official version: <http://dx.doi.org/10.1007/s10436-005-0016-9>.

Open Access version: http://kuscholarworks.ku.edu/dspace/.

ment cost is sunk, once it is incurred, but this can be relaxed with a disinvestment cost, as explained below. For convenience, there is no depreciation or time-to-build, and once the investment cost is incurred, the project yields a unit flow of output forever. The entrepreneur finances this project with the following limited liability debt contract. If an entrepreneur desires debt $D \leq I,{ }^{6}$ then in exchange for $D$, he agrees to give the lender a first claim on project revenues up to a fixed coupon $C$, determined by the lender. If revenue is below $C$, the entrepreneur's liability is limited to available revenue, and he turns over the entire revenue to the lender. There is no benefit from selling the project, because the investment is irreversible, and therefore, the lender does not foreclose the project when revenue is below coupon, and the project continues to produce output forever.

The lender knows the project's price process, and output is observable. The lender has access to funds at the risk-free rate $r$. For example, we may think of a lender as a bank with access to consumer deposits. The lender cannot directly invest in the project; it is only the entrepreneur that has an opportunity to invest. ${ }^{7}$ The lending sector is competitive, so that in equilibrium, the coupon set by the lender offsets the expected loss to the lender from

\footnotetext{
${ }^{6}$ As mentioned above, this analysis takes the debt decision as given, and focuses on the effect of debt on the optimal investment threshold. An entrepreneur might decide to utilize debt for several reasons: perhaps investment cost is large and cannot be financed by savings or retained earnings, or perhaps there is a firstmover advantage and quick entry into a project might yield some monopoly rents, or perhaps there is a tax advantage for using debt, or perhaps debt is relatively cheaper in times of expansionary monetary policy. See also, for example, Lambrecht (2001), Mello and Parsons (1992), and Mauer and Triantis (1994). In particular, this paper does not consider the problem of optimal capital structure, for example, in the spirit of Jensen and Meckling (1976), Myers (1977), (including extensions to real options by Mauer and Ott (2000), and by Nachman (2003),) Brander and Lewis (1986), Brander and Lewis (1988), Leland (1994), and Leland and Toft (1996), and others.

${ }^{7}$ For example, an entrepreneur might have a monopoly right, such as a patent, or she might have some specialized knowledge to produce a particular output, or a bank might be prohibited by law from equity investment in a project.
} 
Sabarwal, Tarun (2005): "The Non-Neutrality of Debt in Investment Timing: A

New NPV Rule," Annals of Finance, 1(4), 433-445. Publisher's official version: <http://dx.doi.org/10.1007/s10436-005-0016-9>.

Open Access version: http://kuscholarworks.ku.edu/dspace/.

future default, and the net value of the project to the lender is zero. ${ }^{8}$

The entrepreneur's problem is mathematically the same as in a simple version of Pindyck (1988). ${ }^{9}$ The entrepreneur's profit flow is given by $\pi^{E}(C, P)=\max (P-C, 0)$. For fixed $C$, using Ito's lemma, the value of this project to the entrepreneur, denoted $V^{E}(C, P)$, satisfies

$$
V^{E}(C, P)= \begin{cases}B_{1} P^{\beta_{1}}+B_{2} P^{\beta_{2}}+\frac{P}{\delta}-\frac{C}{r} & \text { if } P \geq C, \text { and } \\ K_{1} P^{\beta_{1}}+K_{2} P^{\beta_{2}} & \text { if } P<C .\end{cases}
$$

The terms $\beta_{1}>1$ and $\beta_{2}<0$ are solutions to the quadratic equation $\frac{1}{2} \sigma^{2} \beta(\beta-1)+(r-$ $\delta) \beta-r=0$, and the terms $B_{1} P^{\beta_{1}}$ and $K_{2} P^{\beta_{2}}$ are related to speculative bubbles, which are ruled out by assumption, implying that $B_{1}=0$ and $K_{2}=0$. Standard value matching and smooth pasting conditions (at $P=C$ ) give

$$
B_{2}=\frac{C^{1-\beta_{2}}}{\beta_{1}-\beta_{2}}\left(\frac{\beta_{1}}{r}-\frac{\beta_{1}-1}{\delta}\right)>0, \text { and } K_{1}=\frac{C^{1-\beta_{1}}}{\beta_{1}-\beta_{2}}\left(\frac{\beta_{2}}{r}-\frac{\beta_{2}-1}{\delta}\right)>0
$$

Notice that $B_{2}$ is a function of $C$. When convenient, the dependence of $B_{2}$ on $C$ is denoted $B_{2}(C)$

For $P \geq C$, the value of the project to the entrepreneur is the expected present value of capitalized revenues $\frac{P}{\delta}$ minus the capitalized value of the sure coupon flow $\frac{C}{r}$ adjusted for his benefit from future default when revenue is below coupon, given by $B_{2} P^{\beta_{2}}$.

The entrepreneur has an option to delay investment, if he so chooses. For fixed debt $D$ and coupon $C$, the entrepreneur's problem is to determine the revenue threshold (or equivalently, the demand threshold) that maximizes the value of this project to him, and he invests at the

\footnotetext{
${ }^{8}$ The model is described for the case of a risk-neutral entrepreneur and lender. Alternatively, using a standard change-of-measure, the results here are true with the same degree of risk-aversion for both an entrepreneur and a lender.

${ }^{9}$ This formulation is well-known, and is presented in Pindyck (1991), and in Dixit and Pindyck (1994), chapter 6 , as a model in which a firm can costlessly suspend and resume operations. This paper presents a different application of that model, and therefore, details are presented here both for completeness, and to aid appropriate interpretation of that model.
} 
Sabarwal, Tarun (2005): "The Non-Neutrality of Debt in Investment Timing: A

New NPV Rule," Annals of Finance, 1(4), 433-445. Publisher's official version: <http://dx.doi.org/10.1007/s10436-005-0016-9>.

Open Access version: http://kuscholarworks.ku.edu/dspace/.

first time when revenue (or demand) crosses this threshold. For fixed $C$ and $D$, the value of his option to invest in this project, denoted $F(P)$, is given by $F(P)=A_{1} P^{\beta_{1}}+A_{2} P^{\beta_{2}}$. The no-arbitrage, smooth-pasting, and absorbing barrier at zero boundary conditions are
(1) $F\left(P^{*}\right)=V^{E}\left(C, P^{*}\right)-(I-D)$,
(2) $F_{P}\left(P^{*}\right)=V_{P}^{E}\left(C, P^{*}\right)$, and
(3) $F(0)=0$.

Consequently, the optimal threshold $P$ satisfies

$$
\left(\beta_{1}-\beta_{2}\right) B_{2} P^{\beta_{2}}+\left(\beta_{1}-1\right) \frac{P}{\delta}-\beta_{1}\left(\frac{C}{r}+I-D\right)=0 .
$$

Notice that, for fixed $C$ and $D$, the entrepreneur's problem is mathematically the same as the one in which there is a fixed operating cost $C$, cost of investment $I-D$, and operations that can be costlessly suspended and resumed. In that interpretation, $B_{2} P^{\beta_{2}}$ is the expected present value to the entrepreneur from costlessly suspending operations when revenue falls below cost.

In the formulation in this paper, the project continues to operate even when revenue is below coupon, but the entrepreneur's profit is zero, because revenue is turned over to the lender. Therefore, $B_{2} P^{\beta_{2}}$ is the expected present value to the entrepreneur from not having to pay coupon when revenue falls below coupon; in other words, it is the value to the entrepreneur from defaulting when revenue falls below coupon. Default correspondingly reduces the value of the project to the lender. In this paper, the term $B_{2} P^{\beta_{2}}$ denotes the default value of a project. In equilibrium, default is not costless, because the lender sets coupon to offset the default value of a project, as shown below.

Applying a well-known result by Pindyck (1988), for fixed $C$ and $I-D$, the entrepreneur will invest only when $P>C$, and the equation for his optimal threshold has a unique solution for $P$, where $P>C$.

The lender's problem is formulated as follows. The lender's profit flow is given by $\pi^{L}(C, P)=\min (C, P)$. For fixed $C$, the value of this project to the lender evolves with 
$P$, and using the same technique as above, satisfies

$$
V^{L}(C, P)=\left\{\begin{array}{lll}
B_{1}^{L} P^{\beta_{1}}+B_{2}^{L} P^{\beta_{2}}+\frac{C}{r} & \text { if } \quad P \geq C, \text { and } \\
K_{1}^{L} P^{\beta_{1}}+K_{2}^{L} P^{\beta_{2}}+\frac{P}{\delta} & \text { if } \quad P<C .
\end{array}\right.
$$

As above, the terms $\beta_{1}>1$ and $\beta_{2}<0$ are solutions to the quadratic equation $\frac{1}{2} \sigma^{2} \beta(\beta-$ 1) $+(r-\delta) \beta-r=0$, and the terms $B_{1}^{L} P^{\beta_{1}}$ and $K_{2}^{L} P^{\beta_{2}}$ are associated with speculative bubbles, which are ruled out by assumption, implying that $B_{1}^{L}=0$ and $K_{2}^{L}=0 .{ }^{10}$ The value matching and smooth pasting conditions with respect to $P$ imply (at $P=C$ ),

$$
\begin{aligned}
B_{2}^{L} C^{\beta_{2}} & =K_{1}^{L} C^{\beta_{1}}+\frac{C}{\delta}-\frac{C}{r}, \text { and } \\
\beta_{2} B_{2}^{L} C^{\beta_{2}-1} & =\beta_{1} K_{1}^{L} C^{\beta_{1}}+\frac{1}{\delta},
\end{aligned}
$$

from which it follows that

$$
B_{2}^{L}=\frac{C^{1-\beta_{2}}}{\beta_{1}-\beta_{2}}\left(\frac{\beta_{1}-1}{\delta}-\frac{\beta_{1}}{r}\right)=-B_{2}, \text { and } K_{1}^{L}=\frac{C^{1-\beta_{1}}}{\beta_{1}-\beta_{2}}\left(\frac{\beta_{2}-1}{\delta}-\frac{\beta_{2}}{r}\right)=-K_{1} .
$$

For $P \geq C$, the value of the project to the lender is the capitalized value of the sure coupon flow $\frac{C}{r}$ adjusted for the expected loss in present value from default $B_{2}^{L} P^{\beta_{2}}$. In other words, if the lender sets coupon $C$, and price is $P$, the expected present value of this project to the lender is $\frac{C}{r}-B_{2} P^{\beta_{2}}$. Because the entrepreneur invests only when $P \geq C$, the zero profit condition for the lender is

$$
0=V^{L}-D=\frac{C}{r}-D-B_{2} P^{\beta_{2}}
$$

Thus, for fixed $D$ and $P$, the lender chooses coupon to cover both the debt extended, and its expected losses from future default. ${ }^{11}$

\footnotetext{
${ }^{10}$ When $P$ is very large, default probability is very low, implying that the value of the project to the lender is close to $\frac{C}{r}$, and therefore $B_{1}^{L}=0$. When $P$ is close to zero, the value of the project is close to $\frac{P}{\delta}$, so $K_{2}^{L}=0$.

${ }^{11}$ Irreversibility can be replaced by a constant cost of disinvestment equal to $K_{1} C^{\beta_{1}}$, which equals $\frac{C}{\beta_{1}-\beta_{2}}\left(\frac{\beta_{1}}{r}-\frac{\beta_{1}-1}{\delta}\right)$, and this makes the lender strictly prefer to remain in the project when the entrepreneur
} 
Sabarwal, Tarun (2005): "The Non-Neutrality of Debt in Investment Timing: A

New NPV Rule," Annals of Finance, 1(4), 433-445. Publisher's official version: <http://dx.doi.org/10.1007/s10436-005-0016-9>.

Open Access version: http://kuscholarworks.ku.edu/dspace/.

Notice that independent of the definition of equilibrium given below, the total value of an already-in-place project, that is, the sum of the value of the project to the entrepreneur and to the lender, is $V=V^{F}+V^{L}=\frac{P}{\delta}$. In the theory of investment under uncertainty, $V=\frac{P}{\delta}$ is the fundamental value of a project, and for a continuing project, it is unaffected by the choice of debt level. This follows from frictionless debt markets, and in this narrow sense, for a continuing project, the Modigliani-Miller theorem holds in this model.

For a given debt level, the investment problem is to determine a coupon level and a price level that simultaneously satisfy both the optimality condition for the entrepreneur and the zero profit condition for the lender. The discussion above suggests the following definition of an equilibrium. For a given debt level $D \leq I$, an equilibrium for the investment problem is a pair $\left(C^{*}, P^{*}\right)$ such that $C^{*} \leq P^{*}$,

$$
\begin{aligned}
\left(\beta_{1}-\beta_{2}\right) B_{2}\left(C^{*}\right)\left(P^{*}\right)^{\beta_{2}}+\left(\beta_{1}-1\right) \frac{P^{*}}{\delta}-\beta_{1}\left(\frac{C^{*}}{r}+I-D\right) & =0, \text { and } \\
\frac{C^{*}}{r}-D-B_{2}\left(C^{*}\right)\left(P^{*}\right)^{\beta_{2}} & =0 .
\end{aligned}
$$

The following theorem shows that the investment problem is well-defined.

Theorem 1. There is a non-empty, open interval $(0, \bar{D}) \subset[0, I]$, such that for every $D^{*} \in$ $(0, \bar{D})$, there is a unique equilibrium $\left(C^{*}, P^{*}\right)$ to the investment problem.

Proof. Let $P(C, D)=\frac{\delta \beta_{1}}{\beta_{1}-1} I+\frac{\delta \beta_{2}}{\beta_{1}-1}\left(\frac{C}{r}-D\right)$ and $g(C, D)=\frac{C}{r}-D-B_{2}(C) P(C, D)^{\beta_{2}}$. It follows that $\frac{1}{P(C, D)} \leq \frac{1}{\frac{\delta \beta_{1}}{\beta_{1}-1} I+\frac{\delta \beta_{2}}{\beta_{1}-1}\left(\frac{C}{r}\right)}$, so that $\lim _{C \rightarrow 0} \frac{C}{P(C, D)}=0$ (independently of $D$ ). Therefore, there is $C^{o}>0$ (independent of $D$ ) such that $C \leq C^{o} \Rightarrow C \leq P(C, D)$, and also that

$$
C^{o}\left(\frac{1}{r}-\frac{1}{\beta_{1}-\beta_{2}}\left(\frac{\beta_{1}}{r}-\frac{\beta_{1}-1}{\delta}\right)\left(\frac{C^{o}}{P\left(C^{o}, D\right)}\right)^{-\beta_{2}}\right)>0 .
$$

defaults. Moreover, in case of default, a variable cost of disinvestment equal to $K_{1} P^{\beta_{1}}+\epsilon$, for any $\epsilon>0$, again makes the lender strictly prefer to not disinvest. A more detailed analysis would reveal these bounds to be upper bounds for disinvestment cost, because a new entrepreneur would also have some option value, and therefore, he would accept this project only at a fraction of the project's expected present value. 
Sabarwal, Tarun (2005): "The Non-Neutrality of Debt in Investment Timing: A

New NPV Rule," Annals of Finance, 1(4), 433-445. Publisher's official version: <http://dx.doi.org/10.1007/s10436-005-0016-9>.

Open Access version: http://kuscholarworks.ku.edu/dspace/.

Notice that when viewed as a function of $D$, the left hand side of the inequality above is an increasing function and is bounded away from zero, so there is a non-empty open interval $(0, \bar{D})$, which we may take to be a subset of $[0, I]$, such that for every $D^{*}$ in this interval,

$$
C^{o}\left(\frac{1}{r}-\frac{1}{\beta_{1}-\beta_{2}}\left(\frac{\beta_{1}}{r}-\frac{\beta_{1}-1}{\delta}\right)\left(\frac{C^{o}}{P\left(C^{o}, D^{*}\right)}\right)^{-\beta_{2}}\right)>D^{*}>0 .
$$

The last condition is equivalent to $g\left(C^{o}, D^{*}\right)>0$. Moreover, $g\left(0, D^{*}\right)=-D^{*}<0$. As $g$ is continuous, there is $C^{*} \leq C^{o}$ such that $g\left(C^{*}, D^{*}\right)=0$. Let $P^{*}=P\left(C^{*}, D^{*}\right)$. Then for debt level $D^{*},\left(C^{*}, P^{*}\right)$ is an equilibrium.

To verify uniqueness, suppose for debt level $D,\left(C_{1}, P_{1}\right)$ and $\left(C_{2}, P_{2}\right)$ are two equilibria. Without loss of generality, suppose $C_{1} \leq C_{2}$. If $C_{1}<C_{2}$, then $P_{1}>P_{2}$, so that the entrepreneur strictly prefers the lower coupon $C_{1}$, and thus $\left(C_{2}, P_{2}\right)$ is not an equilibrium. Therefore, $C_{1}=C_{2}$, whence $P_{1}=P_{2}$.

\section{The Non-Neutrality of Debt: A New NPV Rule}

The results in the previous section show that at debt level $D$, the equilibrium investment threshold satisfies a new NPV rule:

$$
\frac{P^{*}}{\delta}=\frac{\beta_{1}}{\beta_{1}-1} I+\frac{\beta_{2}}{\beta_{1}-1}\left(\frac{C^{*}}{r}-D\right)
$$

that is, an entrepreneur invests at the first time when total expected present value of the project $\left(\left(V^{F}\right)^{*}+\left(V^{L}\right)^{*}=V^{*}=\frac{P^{*}}{\delta}\right.$, given on the left-hand side of the equality) exceeds the right-hand side of the equality.

In the basic model of irreversible investment under uncertainty, the standard NPV rule for the investment threshold $V^{*}$ is given by the term $\frac{\beta_{1}}{\beta_{1}-1} I$. The new NPV rule has a lower threshold, because $\frac{\beta_{2}}{\beta_{1}-1}\left(\frac{C^{*}}{r}-D\right)<0$. (Notice that $\beta_{1}>1, \beta_{2}<0$, and $\frac{C^{*}}{r}-D>0$.) The new rule shows that the presence of any debt lowers the investment threshold from that consistent with the standard NPV rule. 
Does the presence of debt lead to an investment threshold lower than investment cost? In the model here, the investment threshold is always greater than investment cost. Therefore, the value of waiting is always positive. To compare the new investment threshold with investment cost, notice that if $\left(C^{*}, P^{*}\right)$ is the equilibrium at debt level $D$, then $\left.\frac{\partial g}{\partial C}\right|_{\left(C^{*}, D\right)} \geq 0$. This is because $g(\cdot, D)$ is concave everywhere $\left(\frac{\partial^{2} g}{\partial C^{2}}<0\right)$, so it has at most two zeros, and the proof of the theorem above shows that the smaller of the two zeros is an equilibrium. As $g(0, D)<0$, it must be that $\left.\frac{\partial g}{\partial C}\right|_{\left(C^{*}, D\right)} \geq 0$. The following lemma characterizes when $\frac{\partial g}{\partial C} \geq 0$.

Lemma. Let $\left(C^{*}, P^{*}\right)$ be the equilibrium at debt level $D$. Then

$$
\left.\frac{\partial g}{\partial C}\right|_{\left(C^{*}, D\right)} \geq 0 \Longleftrightarrow \frac{\frac{C^{*}}{r}}{D} \leq \frac{1-\beta_{2}+\frac{\beta_{2} \delta \beta_{2}}{r\left(\beta_{1}-1\right)} \frac{C^{*}}{P^{*}}}{-\beta_{2}+\frac{\beta_{2} \delta \beta_{2}}{r\left(\beta_{1}-1\right)} \frac{C^{*}}{P^{*}}} .
$$

Proof. The condition holds if and only if

$$
\begin{aligned}
-\left(-\beta_{2}+\frac{\beta_{2} \delta \beta_{2}}{r\left(\beta_{1}-1\right)} \frac{C^{*}}{P^{*}}\right) \frac{1}{r}+\left(1-\beta_{2}+\frac{\beta_{2} \delta \beta_{2}}{r\left(\beta_{1}-1\right)} \frac{C^{*}}{P^{*}}\right) \frac{D}{C^{*}} & \geq 0 \\
\frac{1}{r}-\left(1-\beta_{2}+\frac{\beta_{2} \delta \beta_{2}}{r\left(\beta_{1}-1\right)} \frac{C^{*}}{P^{*}}\right)\left(\frac{1}{r}-\frac{D}{C^{*}}\right) & \geq 0 \\
\Longleftrightarrow \quad \frac{1}{r}-\left(1-\beta_{2}\right)\left(\frac{1}{r}-\frac{D}{C^{*}}\right)-\frac{\beta_{2} \delta \beta_{2}}{r\left(\beta_{1}-1\right)} \frac{1}{P^{*}}\left(\frac{C^{*}}{r}-D\right) & \geq 0 \\
\Longleftrightarrow \quad \frac{1}{r}-\left(1-\beta_{2}\right) \frac{B_{2}\left(C^{*}\right)\left(P^{*}\right)^{\beta_{2}}}{C^{*}}-\frac{\beta_{2} \delta \beta_{2}}{r\left(\beta_{1}-1\right)} \frac{B_{2}\left(C^{*}\right)\left(P^{*}\right)^{\beta_{2}}}{P^{*}} & \geq 0 \\
\Longleftrightarrow \quad \frac{\partial}{\partial C}\left(\frac{C}{r}\right)-\frac{\partial}{\partial C}\left(B_{2} P^{\beta_{2}}\right) & \geq 0,
\end{aligned}
$$

from which the desired conclusion follows.

The following theorem shows that the optimal present value threshold is greater than investment cost, but less than the standard prescription of the theory of irreversible investment under uncertainty.

Theorem 2. Let $\left(C^{*}, P^{*}\right)$ be the equilibrium at debt level $D$. Then

$$
I<\frac{P^{*}}{\delta}<\frac{\beta_{1}}{\beta_{1}-1} I .
$$

Proof. The first inequality holds, because the condition in the previous lemma is equivalent to $\frac{C^{*}}{r}-D \leq \frac{1}{-\beta_{2}+\frac{\beta_{2} \delta \beta_{2}}{r\left(\beta_{1}-1\right)} \frac{C^{*}}{P^{*}}} D$, so that

$$
\frac{\beta_{2}}{\beta_{1}-1}\left(\frac{C^{*}}{r}-D\right) \geq-\frac{1}{\left(\beta_{1}-1\right)+\frac{\delta \beta_{2}}{r} \frac{C^{*}}{P^{*}}} D>-\frac{1}{\beta_{1}-1} D,
$$


Sabarwal, Tarun (2005): "The Non-Neutrality of Debt in Investment Timing: A

New NPV Rule," Annals of Finance, 1(4), 433-445. Publisher's official version: <http://dx.doi.org/10.1007/s10436-005-0016-9>.

Open Access version: http://kuscholarworks.ku.edu/dspace/.

whence

$$
\frac{P^{*}}{\delta}-D>-\frac{1}{\beta_{1}-1} D-D+\frac{\beta_{1}}{\beta_{1}-1} I>I-D .
$$

The second inequality is obvious.

The non-neutrality of debt in investment timing arises from the entrepreneur's option value. This can be seen by re-writing the entrepreneur's optimality condition as

$$
\begin{aligned}
\left(\beta_{1}-1\right) \frac{P}{\delta} & =\beta_{1}(I-D)+\beta_{1}\left(\frac{C}{r}-B_{2}(C) P^{\beta_{2}}\right)+\beta_{2} B_{2}(C) P^{\beta_{2}} \\
& =\beta_{1}(I-D)+\beta_{1} V^{L}(C, P)+\beta_{2} B_{2}(C) P^{\beta_{2}} .
\end{aligned}
$$

The investment threshold is affected by three components — the entrepreneur's share of invesment cost, $I-D$, the value of the project that goes to the lender, $V^{L}(C, P)$, and an additional impact of limited liability on the downside risk of a project, $B_{2}(C) P^{\beta_{2}}$. Increases in the entrepreneur's share of investment cost increase the threshold, increases in the lender's share of project value reduce the entrepreneur's share and increase the threshold, and increases in the additional impact of limited liability on downside risk lower the threshold. The lender's zero profit condition implies that the reduction in the entrepreneur's share of investment cost is offset exactly by the value of the project that goes to the lender, and the additional impact from a reduction in downside risk afforded by limited liability lowers the invesment threshold from that consistent with the standard case.

It is important to note that this non-neutrality arises from an entrepreneur's unique investment opportunity. If the lender makes the investment decision, then debt is neutral, and the standard result applies. More generally, in cases where the lender has some influence over the entrepreneur's exercise decision, one would expect a partial effect on investment thresholds. In studying different industries with varying lender influence, this implies a compositional effect of investment thresholds.

This non-neutrality can be motivated in terms of a "bad news principle" (Bernanke (1983)). In the standard theory of irreversible investment under uncertainty, the value of 
Sabarwal, Tarun (2005): "The Non-Neutrality of Debt in Investment Timing: A

New NPV Rule," Annals of Finance, 1(4), 433-445. Publisher's official version: <http://dx.doi.org/10.1007/s10436-005-0016-9>.

Open Access version: http://kuscholarworks.ku.edu/dspace/.

waiting arises from an optimal trade-off between the cost of lost revenue from a postponed investment, and the benefit from postponing an irreversible cost in the presence of adverse demand shocks. In the presence of limited liability debt financing, waiting is valuable, but not as much as it is in the standard case, essentially because "bad news" or adverse realizations after investment are marginally less costly for the firm. ${ }^{12}$

To facilitate a numerical comparison to the standard NPV rule, consider the following parameter values. ${ }^{13}$ A unit of time is one year, the risk-free rate is two percent $(r=0.02)$, uncertainty, as measured by volatility, is twenty percent $(\sigma=0.20)$, the opportunity cost of waiting (also referred to as a convenience yield or proportional dividend yield) is three percent $(\delta=0.03)$, and the investment cost is normalized to $I=100$. For the standard NPV rule, these parameter values yield a threshold that is twice investment cost. As shown in Figure 1, for all $D>0$, the new NPV rule is lower than the standard NPV rule, and this difference increases when a greater fraction of investment cost is debt-financed. If we consider a debt-to-investment cost ratio of 50 percent, ${ }^{14}$ then the overstatement of the standard NPV rule is about 6 percent, with debt financing at 80 percent, it is about 17 percent, and this overstatement can be as much as 30 or 35 percent for higher debt levels.

[Insert Figure 1 here.]

\footnotetext{
${ }^{12}$ For a continuing project, at the intensive margin, there is a standard effect of uncertainty on project value, both to the entrepreneur and to the lender, and in this paper, this effect for each player is equal but in the opposite direction, but on the extensive margin, debt plays an additional role affecting option value.

${ }^{13}$ These parameter values are mentioned in McDonald and Siegel (1986) and in Dixit and Pindyck (1994).

${ }^{14}$ For the nonfarm nonfinancial corporate sector in the United States, the ratio of debt to tangible assets was about 45 percent during the period 1990-2001, and the ratio of debt minus commercial paper to tangible assets minus inventories was about 50 percent over the same period. These figures would give lower estimates for debt financing on a representative new project, because debt amortizes over the life of the loan, whereas the investment cost is measured at replacement cost. Other researchers have mentioned lower numbers for debt financing; for example, see Gomes (2001).
} 
Sabarwal, Tarun (2005): "The Non-Neutrality of Debt in Investment Timing: A

New NPV Rule," Annals of Finance, 1(4), 433-445. Publisher's official version: <http://dx.doi.org/10.1007/s10436-005-0016-9>.

Open Access version: http://kuscholarworks.ku.edu/dspace/.

The investment threshold implied by the new NPV rule compares to those implied by Tobin's $q$ or Jorgenson's user cost of capital in a manner similar to that implied by the standard NPV rule.

Let $q$ be the ratio of the value of a new project to its investment cost. The investment threshold in the spirit of Tobin (1969) would be given by $q^{*}=1$. In contrast, the theorem above shows that $V^{*}=\frac{P^{*}}{\delta}>I$, so $q$ should be adjusted to $q^{*}=\frac{V^{*}}{I}>1$, similar to that implied by the standard NPV rule. Moreover, the $q$ threshold implied by the new NPV rule is obviously lower than that implied by the standard NPV rule.

Similarly, for debt level $D$, if the interest rate on $D$ is $i$, then $i$ is given by $i D=C^{*}$. Therefore, for debt level $D$, the user cost of capital is given by $r \frac{I-D}{I}+i \frac{D}{I}$. Following Jorgenson (1963), let the investment threshold for a new project be that price where price per unit of investment cost equals the user cost of capital. It is well-known that in the partial equilibrium investment model of a firm with fixed operating costs $C$, cost of investment $I$, and costless suspension and resumption of operations, the optimal investment threshold is greater than $r I+C$. In the model in this paper, this translates to $P^{*}>r(I-D)+C^{*}$. As

$$
r(I-D)+C^{*}=\left(r \frac{I-D}{I}+i \frac{D}{I}\right) I
$$

$\frac{P^{*}}{I}$ is greater than the user cost of capital, so that the new NPV rule implies an optimal investment threshold greater than the user cost of capital. This threshold is again lower than that implied by the standard NPV rule.

Alternative limited liability debt contracts yield the same qualitative results. Define a limited liability debt contract as one that limits the liability of the entrepreneur when he cannot pay coupon, so that there is some present value benefit to the entrepreneur (and the same present value loss to the lender) from future default. Consider a particular limited liability debt contract in which coupon is not zero. The dynamics of geometric brownian motion guarantee that the probability of revenue falling below coupon sometime in the future 
is positive, and limited liability then guarantees some present value benefit to the firm (and the same present value loss to the lender) from future default. For a fixed coupon $C$ and revenue $P$, denote this benefit by $\xi(C, P)$. A natural (and fairly weak) assumption on the default benefit is that it is decreasing in revenue - the higher is $P$, the lower is probability of default, and hence the lower is present value benefit from future default. Therefore, suppose $\xi_{P}(C, P)<0$. In this case, the value of the project to the entrepreneur can be written as $\frac{P}{\delta}-\frac{C}{r}+\xi(C, P)$. The optimal investment threshold then satisfies $\left(\beta_{1}-1\right) \frac{P}{\delta}=$ $\beta_{1} I+\beta_{1}\left(\frac{C}{r}-D\right)-\beta_{1} \xi(C, P)+P \xi_{P}(C, P)$. In equilibrium, the lender chooses coupon so that $\frac{C}{r}-D=\xi(C, P)$, and therefore, the optimal threshold satisfies $\left(\beta_{1}-1\right) \frac{P}{\delta}=\beta_{1} I+P \xi_{P}(C, P)$, again confirming the non-neutrality of debt, (because equilibrium $C$ depends on $D$, ) and a lower investment threshold than that prescribed by the standard NPV rule. 
Sabarwal, Tarun (2005): "The Non-Neutrality of Debt in Investment Timing: A

New NPV Rule," Annals of Finance, 1(4), 433-445. Publisher's official version: <http://dx.doi.org/10.1007/s10436-005-0016-9>.

Open Access version: http://kuscholarworks.ku.edu/dspace/.

\section{References}

Bernanke, B. S. (1983): "Irreversibility, Uncertainty, and Cyclical Investment," Quarterly Journal of Economics, 98(1), 85-106.

Boyarchenko, S. I. (2003): "Irreversible Decisions and Record Setting News Principles," American Economic Review, forthcoming.

Boyarchenko, S. I., And S. Z. Levendorsk ̌ (2000): "Entry and Exit Strategies Under Non-Gaussian Distributions," in Project Flexibility, Agency, and Competition, ed. by M. J. Brennan, and L. Trigeorgis, pp. 71-84. Oxford University Press.

Brander, J. A., And T. R. Lewis (1986): "Oligopoly and Financial Structure: The Limited Liability Effect," American Economic Review, 76(5), 956-970.

\section{Economics, 21(2), 221-243.}

Brennan, M. J., And L. Trigeorgis (eds.) (2000): Project Flexibility, Agency, and Competition Oxford University Press.

Dixit, A. K. (1989): "Entry and Exit Decisions Under Uncertainty," Journal of Political Economy, 97(3), 620-638.

\section{2.}

(1992): "Investment and Hysteresis," Journal of Economic Perspectives, 6(1), 107-

Dixit, A. K., AND R. S. PindycK (1994): Investment Under Uncertainty. Princeton University Press.

Gomes, J. F. (2001): "Financing Investment," American Economic Review, 91(5), 12631285.

Jensen, M. C., And W. H. Meckling (1976): "Theory of the Firm: Managerial Behavior, Agency Costs, and Ownership Structure," Journal of Financial Economics, 3(4), 305-360.

Jorgenson, D. (1963): "Capital Theory and Investment Behavior," American Economic Review, 53(1), 247-259.

Krasa, S., And A. P. Villamil (2000): "Optimal Contracts When Enforcement Is a Decision Variable," Econometrica, 68(1), 119-134.

Lambrecht, B. M. (2001): "The Impact of Debt Financing on Entry and Exit in a Duopoly," The Review of Financial Studies, 14(3), 765-804.

Leland, H. E. (1994): "Corporate Debt Value, Bond Covenants, and Optimal Capital Structure," Journal of Finance, 49(4), 1213-1252. 
Sabarwal, Tarun (2005): "The Non-Neutrality of Debt in Investment Timing: A

New NPV Rule," Annals of Finance, 1(4), 433-445. Publisher's official version: <http://dx.doi.org/10.1007/s10436-005-0016-9>.

Open Access version: http://kuscholarworks.ku.edu/dspace/.

Leland, H. E., And K. B. Toft (1996): "Optimal Capital Structure, Endogenous Bankruptcy, and the Term Structure of Credit Spreads," Journal of Finance, 51(3), 9871019.

Mauer, D. C., And S. H. Otт (2000): "Agency Costs, Underinvestment, and Optimal Capital Structure: The Effect of Growth Options to Expand," in Project Flexibility, Agency, and Competition, ed. by M. J. Brennan, and L. Trigeorgis, pp. 151-179. Oxford University Press.

Mauer, D. C., And A. J. Triantis (1994): "Interactions of Corporate Financing and Investment Decisions: A Dynamic Framework," Journal of Finance, 49(4), 1253-1277.

McDonald, R., And D. R. Siegel (1986): "The Value of Waiting to Invest," Quarterly Journal of Economics, 101(4), 707-727.

Mello, A. S., And J. E. Parsons (1992): "Measuring the Agency Cost of Debt," Journal of Finance, 47(5), 1887-1904.

Merton, R. C. (1977): "On the Pricing of Contingent Claims and the Modigliani-Miller Theorem," Journal of Financial Economics, 5(2), 241-249.

Miller, M. H., And F. Modigliani (1958): "The Cost of Capital, Corporate Finance and the Theory of Investment," American Economic Review, 48(3), 261-297.

Myers, S. C. (1977): "Determinants of Corporate Borrowing," Journal of Financial Economics, 5(2), 147-175.

Nachman, D. C. (2003): "Timing Ventures: The Underinvestment Problem," Mimeo. Georgia State University.

PindyCK, R. S. (1988): "Irreversible Investment, Capacity Choice, and the Value of the Firm," American Economic Review, 78(5), 969-985.

(1991): "Irreversibility, Uncertainty, and Investment," Journal of Economic Literature, 29(3), 1110-1148.

Stiglitz, J. (1969): "A Re-Examination of the Modigliani-Miller Theorem," American Economic Review, 59(5), 784-793.

Tobin, J. (1969): "A General Equilibrium Approach to Monetary Theory," Journal of Money, Credit and Banking, 1(1), 15-29.

Townsend, R. (1979): "Optimal Contracts and Competitive Markets with Costly State Verification," Journal of Economic Theory, 21(2), 265-293.

Wallace, N. (1981): "A Modigliani-Miller Theorem for Open-Market Operations," American Economic Review, 71(3), 267-274. 
Sabarwal, Tarun (2005): "The Non-Neutrality of Debt in Investment Timing: A

New NPV Rule," Annals of Finance, 1(4), 433-445. Publisher's official version: <http://dx.doi.org/10.1007/s10436-005-0016-9>.

Open Access version: http://kuscholarworks.ku.edu/dspace/.

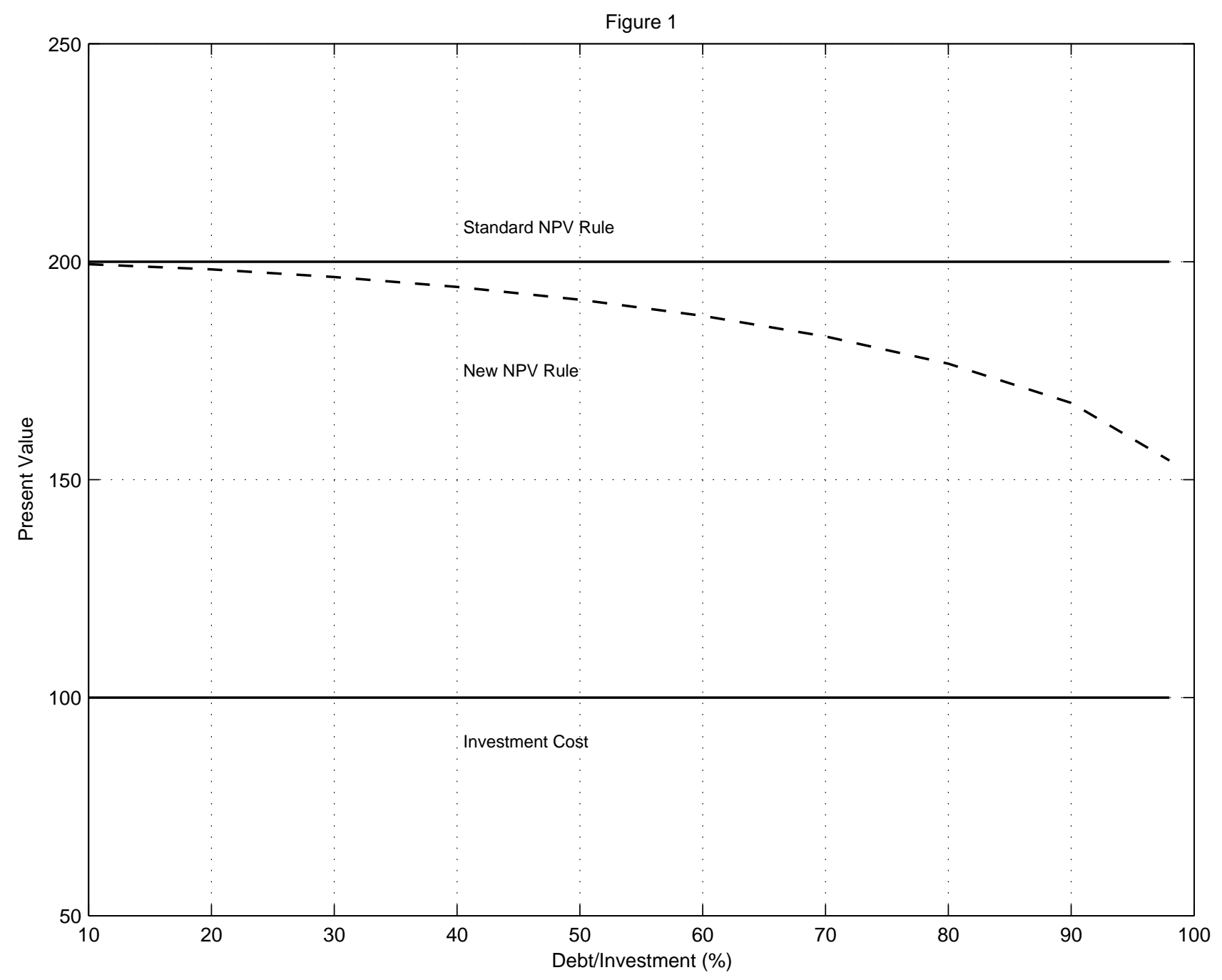

Figure 1: Comparative Statics of Debt Financing

Parameter values are fixed at $r=.02, \sigma=0.20, \delta=0.03$, and $I=100$. 